Јелица Рајковић

HBIS GROUP Serbia

Iron \& Steel
821.111.09-31 Макјуан И.

https://doi.org/10.18485/climb.2017.5.2.ch21

\title{
MАКЈУАНОВА СУБОТА КАО БОЈНО ПОЉЕ НАУКЕ И УМЕТНОСТИ
}

\section{Сажетак}

Ијан Макјуан један је од писаца који у својим делима представљају резултат своје фанатичне посвећености теми којом се баве. Он се није устезао да изађе из своје сигурне зоне, свог света писане речи и маниром правог стручњака упија нове информације из извора других грана уметности, других области људске делатности. Субота је репрезентативни пример Макјуанове свестраности и посвећености, конкретно науци и научном аспекту људског живота. Томе се супротставља сам медијум приказа те привржености, роман, односно уметнички аспекат људског живота. На себи својствен начин, Макјуан приказује ову борбу и ефектно је окончава, остављајући јасну поруку човечанству.

Кључне речи: савремени британски роман, уметност, књижевност, наука, постмодернизам, људски ум, креативност, чињеничност

Прослављени британски писац Ијан Макјуан својеврстан је пример уметника са ренесансним дијапазоном тема које су предмет његовог интересовања. Разноликост тема којима се бави не јењава, већ се ревитализује тиме што се после неког времена Макјуан увек враћа местима која је у неком тренутку своје каријере посетио и у том повратку показује нов, свеж поглед, перспективу зрелости у списатељском и интелектуалном погледу. Науку је већ поставио на пиједестал свог интересовања у Истрајној љубави, али јој се у Субоmи враћа кроз директну конфронтацију са уметношћу.

У роману Субота ликови су архетипи различитих врста личности, различитих начина живота. Такође, у овом роману већина 
представља рефлексије својих уметничких преференци. Они поседују особине које се подударају са карактеристикама њихових омиљених музичких или књижевних жанрова. Макјуан их вешто обликује тако да се и у сваком сегменту њиховог лика оцртава нека особина која се може повезати са одговарајућом карактеристиком преферираног уметничког жанра.

Отеловљење науке је у лику протагонисте, Хенрија Пероуна. Захваљујући послу којим се бави и чињеници да је врхунски стручњак, егзистенцијални проблеми нису нешто што га мучи. Има супругу са којом дели неизмерну обострану љубав и децу која следе своје снове уз подршку родитеља, ма колико да су ти снови родитељима несхватљиви. Његов кафкијански однос према професији неурохирурга доноси перспективу врхунског стручњака, научног радника који однос према свом послу транспонује на однос према животу и тиме наука постаје његов modus vivendi. Систематичност, одговорност, професионалност, еклектичност и студиозност овог лика видљиве су на самом почетку романа и у начину на који се његова субота одвија -он ју је испланирао до најситнијих детаља, доколица је за њега непознаница. Његов живот је приказан тако да делује као да је сваки сегмент у њему беспрекоран, да је савршен у тој мери да код читалаца изазива завист, а чини се и да Макјуан свесно претерано наглашава ту компоненту идеала како би пад био што трагичнији.

Сцене у роману обилују приказима Пероуновог односа према уметности. Наиме, он показује еклектичност и у том погледу. Књижевност сматра неозбиљном, читање романа губљењем времена, а дела класичне књижевности - досадним. Цени само архитектуру и музику, и то одабране жанрове -оне најближе науци, наравно. Њега класична музика прати током читавог дана, у ауту, у току операције. Она поткрепљује његову озбиљност, а он цени њену предвидивост, уређеност. Хармоничност у класичној музици, где је сваки сегмент на свом месту, где су изненађења немогућа, а импровизација се чак не може ни узети као опција, јесу одлике које Пероун доживљава као блиске себи и свом сензибилитету. И у музици, али и у животу.

Иначе, док ради, воли да слуша музику, углавном Бахове клавирске композиције -Голдбергове варијације, Добро наштимовани клавир, Партите. Најчешће се опредељује за Анџелу Хјуит, Марту Аргерич, понекад за Густава Леонхарта. Кад је посебно добре воље, леже му слободније интерпретације Глена Гулда. (Makjuan, 2008: 25). 
Култура и/или наука

Овде наведени извођачи класичне музике део су музичког канона, универзалне културе и творци ванвременске музике. Између Баховог стваралаштва и Хенријеве професије дакако се може повући паралела и закључити да им је приступ раду заједничка црта. Бах је стварао у доба барока и оставио је трага у музици компонујући дела чија се уметничка лепота донекле огледала и у техничком савршенству, перфектној прецизности и интелектуалној дубини. У својој професији, Бах је био иновативан и предан, што су управо оне одлике које су и Пероуну донеле беспрекорну репутацију врхунског стручњака.

Поред Баха, према чијој музици има највише афинитета, Пероун не може остати имун на музику других значајних аутора, као и сваки искрени поштовалац класичне музике. У том погледу не представља изузетак. „Највише цени Баха, посебно његове композиције за клавијатуре; јуче је у сали слушао две Партите док је радио на Андреином астроцитому. А потом следе уобичајена имена -Моцарт, Бетовен, Шуберт. Његови џез идоли, Еванс, Дејвис, Колтрејн.“ (Makjuan, 2008: 65)

Што се тиче његовог укуса у џез музици, открива нам да исто правило по којем његови афинитети функционишу у класичној музици важи и у џезу. У питању су извођачи који су иновативни, који су доста утицали на џез музику, обогатили је, самосталним, или заједничким деловањем. Иако је у питању популарна музика, заснована на импровизацијама, за разлику од класичне музике која се компонује по строго утврђеним правилима, и у џез музици уочава се извесна еклектика, што је чини интелектуалнијом од других жанрова популарне музике. Ипак, та одлика џеза да буде заснован на импровизацијама, али и да представља фузију многобројних култура, музичких жанрова и традиција услед чега се и одликује разноврсношћу и обиљем музичких елемената, наговештај је онога што ће постати евидентно: Хенријева неоткривена склоност према уметности која се не ограничава само на ове музичке жанрове, већ која се посматра у знатно ширем смислу и обухвата књижевност и друге лепе уметности.

Хенри остаје поред зачеља стола. Иако је све време био свестан музике, тек сада се поново усредсређује на њу. Протекло је више 
од сата и Хјуитова већ свира завршну варијацију Quodlibet -бучну и шаљиву, чак и безобразну, с призвуцима сељачких песама и хране и секса. Последњи ликујући акорди замиру, на секундудве завлада тишина, онда се враћа Арија, по нотама истоветна, али измењена свим претходним варијацијама, једнако нежна, али у исти мах и резигнирана, и сетнија са плутајућим клавирским тоновима који долећу из далека као из неког другог света, и сасвим лагано нестају. (Makjuan, 2008: 237-238).

Хенријев однос према уметности открива се додатно у његовој интеракцији са другим ликовима. Дебате са Дејзи, Хенријевом кћерком песникињом о значају књижевности за човечанство бескрајно су довитљиве и занимљиве, али чини се и саме по себи бескрајне јер у њима нема победника. Дејзи не успева да убеди оца да да шансу књижевности јер је он види као нешто што не може оплеменити човека нити му донети нешто добро, већ као нешто што само тумара по мрачним кутковима његовог бића и извлачи на површину оно најслабије у њему, чинећи га рањивим.

Оно што читаоце наводи на размишљање је „Хенријева теорија о софистицираним бајкама“ (Crumey, 2005, s.a.). Да ли заиста можемо рећи да „теме којима су се бавили Толстој или Флобер више нису релевантне“ (Crumey, 2005, s.a.)? Да ли та постмодернистичка сумња и скепса према традицији, одбацивање канона неумитно може да доведе до тога да сам писац, у овом случају Макјуан, „изгуби веру у сопствени стил писања, будући да је одавно овладао тим традиционалним стилом“ (Crumey, 2005, s.a.)? Наравно, писац се ове теме дотиче са огромном дозом ироније, јер је ово „неслагање Пероуна са Флобером и Толстојем заправо део једне много шире расправе, чија је тематика повезана са функцијом књижевности да надмаши и утеши“ (Bradley, 2005, s.a.). Пероун је, дакле један од елемената постмодернизма у овом роману захваљујући својој скепси и одбацивању традиције.

Интересантно је и то како се Дејзи, Хенријева кћерка, и њен деда, а Хенријев таст Џон Граматикус, такође песник, могу посматрати једно наспрам другог као оличења различитих уметничких, у овом случају књижевних, тенденција. Одвећ је познат Макјуанов анимозитет према старијим генерацијама књижевника британског миљеа. И заиста, не може се оспорити чињеница да је Други светски рат опу- 
Култура и/или наука

стошио не само свет у материјалном, већ и у духовном и интелектуалном смислу. Генерације које су у том периоду стварале нису имале снаге да нађу свежину и иновативност у изразу, те је Макјуан посезао за шокирањем, недостатком цензуре, отвореним говором о табу темама без имало устручавања, тематиком девијантног и изопаченог као оружјем у борби против учмалости и монотоније целокупног књижевног стваралаштва. Мање или више имплицитно, али ипак приметно, неретко је у својим романима провлачио овај моменат борбе старог и новог, младог и остарелог, па се овде кроз својеврсни синегдохски приказ може закључити да је Дејзи оличење полетности и оптимизма нових генерација које имају толико тога да кажу, које су пуне идеја и које неустрашиво пркосе свему што им стане на пут. Са друге стране је Џон Граматикус, представник тих старијих генерација, бард који ужива у свом реномеу и чији его не допушта ниједном птићу, па макар то била и његова унука, да рашири крила сопственог израза и креативности делимично у страху да ће остати у сенци, а делимично из убеђења да је сваки такав покушај осуђен на пропаст, јер је његова слава недостижна било коме другом.

Контраст између Хенрија и његовог сина, Теа, који је блуз музичар, изражен је у погледу музичких жанрова које преферирају. Његова посвећеност овом музичком жанру и изражени уметнички сензибилитет огледају се у његовом начину живота. Склоност ка импровизацији на сцени, посвећеност чулном и емотивном аспекту живота представљају нешто што Хенри не разуме, нарочито што окружење у којем је Тео одрастао није било такво. Ипак, та средина била је довољно здрава да пружи Теу охрабрење да следи своје снове и инстинкте па он никада није наишао на неодобравање својих родитеља.

Склоност ка науци довела је до тога да Хенри живи свој живот под својеврсним стакленим звоном које ће услед три снажна ударца пући и указати Хенрију да су сигурност и ушушканост којима се потпуно био препустио само привид.

Први ударац задаје уметност, музика прецизније, наступ Теовог блуз бенда. Доживљај музике коју тај бенд изводи представља један неочекивани догађај тог дана. Пероун остаје беспомоћан пред вртлогом емоција које та музика у њему изазива и пред којом не успева да устукне иза свог штита научног рационализма. Бива при- 
моран да положи оружје пред уметничком лепотом (коју иначе не признаје) и увучен у магични свет блуза.

Више нимало уморан, Хенри се одваја од зида на који се све време наслањао, и креће ка средини мрачног аудиторијума, у сусрет моћној звучној машини. Препушта се њеном загрљају. Има тих ретких тренутака кад музичари заједно дотакну нешто умилније од свега што су икад искусили на пробама или наступима, нешто што превазилази обичну сарадњу и техничку увежбаност, кад изразом досегну исту ону лакоћу и склад који одликују пријатељство или љубав. Тада нам музичари дају прилику да начас завиримо у оно што бисмо могли бити, оно најбоље у нашем бићу, у један немогућ свет у коме све што имаш дајеш другима, али од себе ништа не губиш. Тамо напољу, у стварном свету, постоје детаљни планови, визионарски пројекти за мирољубива царства, у којима су сви сукоби разрешени, и има среће за све, за сва времена -химере за које су људи спремни да гину и убијају. Христово царство на земљи, раднички рај, идеална исламска држава. Али само у музици, и само у ретким приликама, завеса се одиста подиже да би разоткрила тај сан о заједништву, и призор је дочаран замамно и неодољиво, пре него што избледи са последњим тоновима. (Makjuan, 2008: 161).

Занесен мелодијом, Пероун као да на тренутак заборавља на свој став према уметности, а читалац има прилику да види да и његово научно становиште није неосвојива тврђава и да може бити срушена или бар уздрмана до темеља, што ће се касније и десити, а овде се само наговештава. Макјуан се у овом одломку ставља у позицију некога ко толико добро разуме музику да је у стању да осети какви су ефекти синергије музичара на сцени.

Одломак започиње нарацијом у трећем лицу говорећи о Пероуну, али се убрзо пребацује у причу о музичарима, још увек у трећем лицу, али сада из перспективе музичара. Описује какав је осећај бити на сцени, када се осети нова енергија, другачија од оне која се осећа иначе, која је узвишена, која достиже вановоземаљске и ванвременске размере, попут сиве птице Клајва Линлија у Амстердаму, неухватљива, нешто чему сваки уметник тежи. У овом роману Макјуан иде корак даље и осликава ефекат који таква инспирација има на публику, пошто се преточи у уметничко дело. Управо оно што је циљ уметности: да оплемени, да подучи, да подстакне. 
Култура и/или наука

Зато приповедање у овом одломку можемо вишеструко схватити: приповедање у трећем лицу обавља сам аутор, те нам говори и о Хенрију и о музичарима и о њиховом доживљају на сцени, било из неког свог искуства, било из маште. Друго тумачење могло би се односити на Пероуна који је сада преузео улогу наратора. Реченица пре описа музичара је: Препушта се њеном загрљају. - у којој она је музика.

Епифанија коју Хенри проживљава док слуша извођење Теовог бенда путује до неслућених дубина његове личности као што Одисеј неустрашиво залази у мрачне пећине омамљен песмом сирена. Оно што проналази, успева да уплаши и самог Хенрија. Буде се давно успавани духови његове подсвести, закопани пориви којих се Хенри одрекао онда када је решио да свој живот изгради у складу са конвенцијама друштвено прихватљивог и морално оправданог понашања. Блуз музика својим меланхоличним тоновима мами те пориве да изађу на површину и Хенрија обузимају мисли и идеје о неким лудим и њему потпуно несвојственим поступцима, о нечему чиме би запрепастио све оне који га познају, као да завиди свима онима који прате своје потребе и испуњују своје жеље без обзира на то шта ће други рећи. Помишља чак да купи нови, спортски ауто, да нађе љубавницу. Ипак, успева да се одупре даљем проматрању у том смеру, побеђује заводљиву музику сирена са сцене и отрже се демонима који се враћају тамо одакле су дошли, а он остаје потпуно слуђен и свестан да је потценио моћ блуза. У тим размишљањима се свакако не види његова жеља, јер убрзо и одустаје од помисли, али и да је остао истрајан у томе, то не би био одраз његових истинских жеља и потреба, већ последњи очајнички покушај да исправи грешке из младости и осети узбуђење које је тада пропустио.

Како ли су само он и Розалинд, тако савесни и конвенционални, успели да створе један тако слободан дух? Некога ко се облачи, с дозом ироније, у стилу боемских педесетих, одбија да чита књиге и не пада му на памет да настави школовање, ретко устаје пре један, и коме је животна страст да овлада свим нијансама традиције, Делтом, Чикагом, Мисисипијем, извесним трзајима жице у којима лежи кључ свих мистерија, и успех његовог бенда, Њу Блу Рајдера. (Makjuan, 2008: 29). 
Овде је приметна и блага иритираност у Хенријевом гласу. Можда је он желео наследника у свом начину живота, музичком укусу и начину размишљања. Јер оно што представља Теов предмет интересовања, Хенрија никада није интересовало нити његову супругу као професија о којој треба озбиљно размислити. Ипак, са друге стране, набрајање Теових интересовања у овом одломку, одушевљење блузом и традицијом која стоји иза њега, мистеријом извођења музике на гитари, открива се и Хенријево скривено дивљење, оно којег ни сам није свестан, дивљење према Теовом слободном духу и према његовој решености да иде за својим сновима и остварењем својих циљева и да на путу до њих ужива. Чини се да је Хенри донекле и роб неких мерила и правила понашања у друштву и да је временом научио да живи по њима и пронађе смисао и ужитак, јер другачије није смео и није се усуђивао да ризикује и крене за неким лудим сновима и доживи неуспех, већ је играо на сигурно. Ова претпоставка није експлицитно доказана јер је Макјуан није ни у једном сегменту представио на почетку романа, чак ни између редова скривену, већ је оставио читаоцима да пробају и сами то докуче, све док нам није открио Хенријеве мисли након што је слушао Теову свирку. Хенри је тај сегмент свог живота вероватно угушио одавно, толико да се ни сам тога не сећа, али овакве прилике успевају да пробуде и она сећања која у човеку спавају најдубљим сном.

Али је тај наговештај веома сугестиван: Хенри жали због недостатка слободнијег духа у младости, осећа празнину у свом животу јер је увек играо по правилима и на сигурно, никада није довољно испољио инвентивност и осетио ту дивљу, необуздану и неухватљиву слободу. Није истражио благодети света и опције које су му нуђене, није осетио ништа ван своје професије, па зато се и запита да ли постоји у животу нешто осим спашавања живота. Блуз је, дакле, послужио као окидач за буђење Хенријеве несреће због неиспуњености и неостварености на још неким пољима осим професионалног.

Из његовог излагања имамо утисак да можда и није толико срећан као што се чини. Свакако да воли своју супругу и своју децу, али то што помиње да се млад оженио, као да је хтео да задовољи неке друштвене норме, а не да прати сопствене жеље и потребе, баца сенку на његову срећу и задовољство са почетка романа. Све ове мисли откривају нам суштину његове личности, оно што остане кад скине маску, када ски- 
Култура и/или наука

не са себе слој по слој друштвено прихватљивог и пожељног Хенрија, недодирљивог у својој савршености у послу, браку, породици, богатству. Само је блуз могао да пробуди такве емоције у њему, али их он брзо отреса након свирке и поново навлачи своје слојеве и ставља маску на лице.

Други ударац настаје онда када је његова породица у опасности од ситног криминалца Бакстера коме се замерио раније тог дана. Бакстер се појавио у његовој кући држећи нож уперен у Розалинд, Хенријеву супругу, и приморао Дејзи да гола чита своју песму. Иако је Дејзи читала песму Плажа Довер Метјуа Арнолда, а не своју, како јој је било наређено, Бакстер је био дирнут оним што је чуо. То разумевање и додживљај поезије омогућили су Хенрију и Теу нешто доцније да га савладају.

Оно што је поразило Хенрија у овој ситуацији била је та свест о моћи уметности и књижевности коју је потценио, али нарочито и свест о чињеници да је Бакстер ту песму доживео на начин како он никада није успео и у томе је успео да га надвлада. Чини се да је његова неспособност да се саживи са уметничким делом његова главна мана, па и Ахилова пета у поређењу са Бакстером. Иста та иронија и мудрост наводе и Дејзи и Теа на преиспитивање. Другим речима, сви они ликови који су били пуни самопоуздања, превише сигурни у себе и своја веровања, поклекли су пред истом иронијом и мудрошћу књижевности и уметности. Склоност ка преиспитивању, самоиспитивању, несигурности део су великог постмодернистичког плана који приказује садашњост, али и будућност кроз једну призму несигурности и нејасноћа, замрљаних линија и замагљених обриса.

Између ових догађаја, Пероунови дугачко приповедани монолози фокусирају се на његове модусе сазнавања света: кроз познавање науке, која разуме механизме у мозгу, али не и комплексности индивидуалног ума; кроз медије, за које је уверен да су изокренути и да дају пристрасну слику; и кроз уметност. Веровањем науци, али не и медијима и уметности, Пероун постаје беспомоћан да буде потресен осећањем пропасти због рата у Ираку или да разуме Бакстера довољно добро да би осујетио његов план да нападне породицу Пероун (Wall 5). (цитирано у: Sgarlata, 2009: 81).

Он је захваљујући својој „професији смештен у научни реалм, попут Џоа у Истрајној љубави“ (Padwicki, 2006: 23). Његова професија 
чини да он буде „дубоко укорењен у њој, што се уочава на сваком кораку у његовом резоновању" (Padwicki, 2006: 23) најобичнијих ствари свакодневнице. Дубоко је уверен да се све може артикулисати кроз науку.

Сама ситуација у којој се нашао пред криминалцем представља трећи и коначан ударац за Хенријево стаклено звоно лагодног живота и чини да се оно распрши у милион ситних делова у неповрат. Већ на самом почетку романа, када Хенри наилази на демонстрације против рата у Ираку, видљива је одсуство емпатије код њега. Као и сви реномирани интелектуалци савременог доба, како Макјуан жели да укаже, и Хенри је исувише уроњен у свој идеални свет, микрокосмос који је сам својим знањем и радом изградио, уверен да не постоји ништа што би тај свет могло да уздрма, а о реалним проблемима у свету, без претераног критичког сагледавања, прихвата оно уврежено, мишљење већине. Он не разуме истинске проблеме које тај рат изазива, не зато што не може, већ зато што не жели. За њега су и рат и сиромаштво и други реални проблеми део једне димензије која је паралелна са његовом. Отуд му и храброст у првом суочавању са Бакстером. Знао је да је тада већ његов живот био угрожен, али је лукаво искористио своје предности да изађе као победник из те ситуације. Оно што није могао да претпостави јесте да је то била само једна битка, а не Бакстерова коначна капитулација.

Оно што је касније уследило уздрмало је Хенрија много више. Овог пута није био угрожен само његов живот, већ и живот његове породице. Улог је био далеко већи. Управо је о томе размишљао покушавајући да заспи у освит новог дана. Посматрајући делиће стакленог звона свог научног материјализма, Хенри је најзад био свестан тога да не постоје заштићени слојеви друштва, да нико у условима савременог доба није безбедан и да човек може само обмањивати себе у жељи да поверује у апсолутну сигурност себе и својих ближњих. Колико су сиромашни, толико су и богати изложени нападима криминалаца, терориста и пошасти које не презају од тога да за собом оставе пустош. Једино преостаје вера у боље сутра. Нада да ће снага љубави, породице, пријатељства превладати и донети тако преко потребну сигурност и једино безбедно уточиште за сваког појединца. Након свих ових потреса и револуција које су се одиграле у свету 
Култура и/или наука

Хенрија Пероуна, где је поредак уништен анархистичким снагама чије снаге није ни био свестан, главни јунак овог романа почиње да прихвата и ону другу страну, заузима нешто хуманистичнији приступ. Не одбацује уверења која су уграђена у темеље његовог постојања, али схвата да и у уметности и оним сегментима живота који делују на емоције има лепоте која употпуњује живот сваког људског бића. Неће се без уметности умрети, бар је он доказ томе, али ће се много од животне лепоте пропустити.

Зато нећемо погрешити ако закључимо да је овај роман својеврсна лична изјава којом Макјуан „напада скептицизам модерног романа према науци. Постоје математичке једначине у Дуги гравитације (1973), али Пинчон предлаже да се готово увек користе за кобне, окултне завршетке. Код Дона ДеЛила у Белој буци (1985), технологија ствара токсичне догађаје које носи ваздух и пилуле које стварају погубљеност. Субоma представља технологију у далеко сангвиничнијем светлу. Усхићени описи бријача са више оштрица, радија у ауту и дигиталних камера, што неким читаоцима делује отворено конзумеристички, наговештавају Пероуново дивљење према људском генију који стоји иза сваког инкременталног изума. Макјуанова теорија огледа се у томе да сви ми живимо у проширеном снопу светлости, у време декодираног генома, Хабловог телескопа, илуминације мозга." (Zalewski, 2009, s.a.).

Међутим, попут самопоуздања у причању прича научника који покушавају да открију биолошке корене личних емоција и друштвених веровања, Макјуан одржава веру у посебне задатке уметности. Сматрам да писци могу да залазе на она места која су паралелна са научним истраживањем и никада не могу њиме бити замењена: истраживање наше природе; нашег стања; оно какви смо у одређеним ситуацијама. За Макјуана се стога може рећи да „подржава Лиотаров аргумент да се „научно сазнање не може знати нити учинити познатим, истинским знањем уколико не посегне за другим, наративом“ (29)“. (цитирано у: Padwicki, 2008: 23).

Најзад, Макјуан је показао у својим делима, нарочито у Субо$m u$, да наука не мора да буде изолована од популарне културе. Такође, показао је и то да је објективност само привид, да научно сазнање може да изневери наратора као средство контекстуализације насиља и објашњење терора. Ту се уочава постмодернистички моменат у роману, јер Макјуан, упркос својој склоности ка науци и животном 
интересовању за научне методе и принципе, ставља научни приступ на пробу, преиспитује га и најзад признаје да није искључив, већ да је поента у стварању комплементарног односа између науке и уметности, у овом случају конкретно књижевности: свака од њих има оно што друга нема и удружене, створиће идеал људске креативности и иновативности.

Свима нам је потребно интегрисано образовање. Обе стране имају доста тога да науче једна од друге. За нас који се бавимо хуманистичким наукама, толико је тога узбудљивог и изазовног нарочито у биолошким наукама и много тога што може да да нови полет нашем разумевању људске природе, што је интегрално у студији креативних уметности. Потребно нам је познавање математике и физике како бисмо открили како изгледа истиниска интелектуална потешкоћа. Што се њих тиче, научници морају извући фантастично и предивно наслеђе уметности -оно што се мисли о нашем стању вековима је витални ресурс. Такође, наука мора да култивише и цени своју научну књижевну традицију, од Леонарда и Френсиса Бејкона до Е. О. Вилсона и Стивена Вајнберга, научници су изврсно писали о свему око нас. Такође, млади научници морају се научити јасној комуникацији и учењу предмета заснованих на есејима, као што би историја и енглески језик били витални за обуку у артикулацији идеја. (Henry Ransom Center, s.a.)

Кроз бојно поље науке и уметности Макјуан је представио две дијаметрално супротне доктрине и њихове ревносне борце. Са једне стране је наука која у свему тражи опипљиве доказе и која не признаје догматизам, већ кроз систематичност, аналитичност и организованост тежи објашњењу света. Са друге стране је уметност са својим оружјем -креативношћу, слободним духом, сензуалношћу, емотивношћу.

Кроз већи део романа протагониста Хенри Пероун намеће свој научни материјализам и аналитичко поимање стварности као једино прихватљиво, али сурово бива поражен пред изазовима исте те стварности која указује и на другу страну медаље. Рушење његовог света приказано је најтрагичније, али је Макјуан успео и да ту трагичност обавије велом ироније и примесама подругљивости због Пероунове наивности и својеврсне ограничености у размишљању. Насу- 
прот њему, ликови чији су афинитети наклоњени више уметности и који донекле немају интересовања за науку, а донекле је оспоравају, такође доживљавају пораз. То је нарочито изражено у сцени када Бакстер након упада у кућу Пероунових бива поражен. Сви су сведоци тога да је Хенри искористио знање о Бакстеровој болести као оружје које је на крају свима њима донело спас. Уметност га је ранила, али му је наука изазвала фаталне последице.

Као одговор на питање која страна може да превагне у условима савремене цивилизације, Макјуан проглашава нерешен резултат: за потпуност човекове личности и оствареност његових капацитета неопходан је суживот оба аспекта. Кључ опстанка цивилизације лежи у комплементарности науке и уметности.

\section{Извори и литература}

Bradley, James. A detailed life in the day. The Age. 2005. <http://www.theage.com.au/news/Reviews/A-detailed-life-in-theday/2005/02/11/1108061845069.html>

Crumey, A. 2005. Perils of seizing the day. The Scotsman. $<$ http://www.scotsman.com/lifestyle/culture/books/perils-of-seizing-theday-1-1402260>

Makjuan, Ijan. Subota. Prevod: Arijana Božović. Beograd: Paideia. 2008. Štampano.

Interview with Ian McEwan. Henry Ransom Center. The University of Texas at Austin. $<$ http://www.hrc.utexas.edu/press/releases/2014/imc_qa.html>

Padwicki, Robyn. Intertextual Echoes: Violence, Terror and Narrative in the Novels of Ian McEwan and Graham Swift. 2006.

$<$ https://www.google.rs/url?url=https://open.library.ubc.ca/media/download/pdf /24/1.0066797/1\&rct=j\&frm=1\&q=\&esrc=s\&sa=U\&ved=0ahUKEwibg- fart3RAhXC A5oKHZQrCG0QFggiMAQ\&usg=AFQjCNG5fjgbTNCDr6xckg7YP V_TMEGySw>

Sgarlata, Emily. Desire Versus Conscience: Development of Id and the Ego in Ian McEwan's Fiction. 2009.

<https://baylorir.tdl.org/baylorir/bitstream/handle/2104/5423/Emily_Sgarlata_ maste rs.pdf?sequence $=1>$

Zalewski, Daniel. The Background Hum: Ian McEwan's Art of Unease. The New Yorker. 2009. <http://www.newyorker.com/magazine/2009/02/23/the-background-hum> 


\section{Jelica Rajkovic}

HBIS GROUP Serbia Iron \& Steel

\section{MCEWAN'S SATURDAY AS A BATTLEFIELD OF SCIENCE AND ART}

\section{Summary}

Ian McEwan is one of the writers who present in their works result of their own fanatic dedication to the subject they are dealing with. He did not refrain from leaving his comfort zone, his world of written words and like a true expert he absorbed new information from the sources of other arts, other fields of human activity. Saturday is representative of McEwan's versatility and dedication, specifically to science and scientific aspect of human life. The very medium of representation of this devotion, the novel, i.e. the artistic aspect of human life, opposes it. In his own manner, McEwan depicts this battle terminating it effectively, leaving a clear moral to humanity.

Key words: contemporary British novel, art, literature, science, postmodernism, human mind, creativity, factuality 